\title{
Influence of Internal Seedborne Fusarium semitectum on Cotton Seedlings
}

\author{
Maria L. N. Costa, Onkar D. Dhingra \& Janaina L. da Silva \\ Departamento de Fitopatologia, Universidade Federal de Viçosa, CEP 36570-000, Viçosa, MG, \\ Fax (031) 3899-2240, e-mail: dhingra@ufv.br.
}

(Accepted for Publication 18/10/2004)

Corresponding Author: Maria L. N. Costa

COSTA, M.L.N., DHINGRA, O.D. \& SILVA, J.L. DA. Influence of internal seedborne Fusarium semitectum on cotton seedlings. Fitopatologia Brasileira 30:183-186. 2005.

\begin{abstract}
Fusarium semitectum was found to be the major seed colonizing fungus in the commercial acid delinted cotton (Gossypium hirsutum) seed lots. There was no correlation, however, between its incidence and seedling emergence and disease symptoms on the emerged seedlings in autoclaved sand. Inoculation technique simulating internally seedborne nature of the fungus showed that the observed non-correlation might be related to the threshold level of seed coat colonization. The internally seedborne inoculum besides reducing seedling emergence, incited an array of symptoms on the emerged seedlings, which ranged from negative geotropism, leaf tearing, collar rot leading to dry root rot and seedling mortality. The dry root rot continued to develop on the plants surviving the seedling phase. The collar rot symptoms can be confused with those caused by Rhizoctonia solani.

Additional keywords: negative geotropism, root rot, seedborne inoculum, cotton diseases, Gossypium hirsutum.

\section{RESUMO}

A influência de Fusarium semitectum carregado internamente por semente nas plântulas de algodoeiro

Fusarium semitectum foi o principal fungo colonizador de sementes de algodão (Gossypium hirsutum) nos lotes comerciais deslintados com acido, mas não havia nenhuma correlação entre sua incidência e porcentagem de emergência de plântulas e sintomas de doença nas plântulas emergidas. Técnicas de inoculação simulando infecção interna das sementes pelo fungo mostraram que a ausência de correlação observada pode estar relacionada ao limiar da colonização no tegumento da semente. O inóculo interno nas sementes, além de reduzir a emergência de plântulas, produz um conjunto de sintomas nas plântulas emergidas, que vão do geotropismo negativo, dilaceração de folhas primaria, podridão do colo levando à podridão seca de raízes e mortalidade de plântulas. A podridão de raízes continuou se desenvolvendo nas plântulas sobreviventes resultando em mortalidade na fase pós-plântula.
\end{abstract}

Palavras-chave adicionais: geotropismo negativo, inoculum dentro da semente, doenças do algodoeiro, Gossypium hirsutum.

Seedling diseases are important in the cotton (Gossypium hirsutum L.) cultivation because they lead to poor stand, resulting in gaps in the plant rows and the inoculum produced on them can cause diseases on the adult plants and on capsules affecting productivity and linter quality. Some of the cotton seedlings diseases are caused by the seedborne pathogens especially Colletotrichum gossypii South., $C$. gossypii South. var. cephalosporioides Costa, Fusarium. moniliforme Sheldon, Rhizoctonia. solani Kuhn, and other less frequent seedborne fungi (Ray \& McLaughlin, 1942; Klich, 1986; Julliatii \& Ruano, 1997)

During the routine analysis, using standard blotter test, of the several acid delinted seed samples received by our seed pathology laboratory, no fungal pathogen of known importance was generally detected, but majority of the samples usually yielded $F$. semitectum Berk. \& Rav. in frequencies reaching $70 \%$. Seedling emergence testes in autoclaved sand showed no correlation between the proportion of $F$. semitectum infected seeds and any disease symptoms (percent seedling emergence, lesions on any seedling part and negative geotropism), but isolations from such lesions, whenever they appeared, mostly yielded F.semitectum.

Several species of Fusarium have been isolated from cottonseeds, most reports being about $F$. moniliforme. In the the United States, Fusarium spp. consisting of F. roseum Schwabe, F. moniliforme, F. oxysporum Schlecht, and F. solani (Mart.) Sacc. were found to be most widely distributed and abundant in state of Mississippi (Davis, 1977) and in the Georgia Plains (Roncadori et al., 1971). Klich (1986) found considerable amounts of $F$. semitectum along with other species, in the cottonseed samples collected from the southern states of Alabama, Arizona, South Carolina, Tennessee and Texas, although its incidence and frequency differed from location to location and in different years at the same location depending upon the rainfall and temperature during the growing season. None of these reports however, explores the role of $F$. semitectum on seed and seedling quality. Although F. semitectum and some other Fusarium species isolated from cottonseeds by Ray \& Mclaughlin (1942) were equally pathogenic in the seedling inoculation testes, the data did not 
explain the role of seedborne $F$. semitectum in seedling diseases.

In Brazil, reports about the occurrence of Fusarium in cottonseeds are restricted only to Fusarium spp. without specifying the species involved and their effect on seed and seedlings (Pizzinatto et al., 1994; Soave et al., 1999). Therefore the importance of F. semitectum in the Brazilian acid delinted cottonseed is not known. This fungus is common in seeds of dicotyledonous crops growing in warm and humid climates, and in legume crops like soybeans and dry beans it constitutes the major portion of Fusarium species that colonize seed. In these two crops the seedborne $F$. semitectum can cause seed rot, collar rot and root rot, with significant correlation between proportion of infected seeds in a sample and percent seedling emergence and seedling collar rot (Dhingra, 1978; Dhingra \& Muchovej, 1979; Dhingra \& Acuña, 1997).

The following study was done to determine the role of seedborne $F$. semitectum on seedling emergence and seedling diseases and determine the cause of inconsistency in the symptom development on seedlings when cottonseed lots containing high proportion of contaminated seeds are planted in sterile sand.

A sample of acid delinted cottonseed 'Makra' was used in all the tests. This samples was selected because of high seedling emergence rate $(97 \%)$ in autoclaved sand, and production of lesion free seedlings. The blotter test revealed incidence of Aspergillus flavus Link (2\%) and A. glaucus Link (3\%).

The isolate of $F$. semitectum was randomly picked from a cottonseed during the routine blotter testes. Initially for seed inoculation, the conidia of the fungus were produced on potato sucrose agar in culture plates at $25{ }^{\circ} \mathrm{C}$ under near ultra violet light (12 $\mathrm{h}$ photoperiod). To collect the conidia, the culture plates were flooded with $10 \mathrm{ml}$ of water, and the conidia were dislodged using a soft brush. The conidial suspension thus obtained was collected in a beaker and the conidial concentration was adjusted to $10^{6} / \mathrm{ml}$. Cottonseeds were inoculated by spraying $20 \mathrm{ml}$ of the suspension on $300 \mathrm{~g}$ seeds in a laboratory scale rotatory seed treater. The seeds were kept rotating until surface moisture had dried. The control seeds were treated similarly with water only. These seeds when planted in autoclaved sand, emerged normally and no disease symptoms developed on the seedlings, which indicated that the externally seedborne inoculum of $F$. semitectum did not affect seed and seedling quality of a cottonseed lot.

To simulate internally seedborne inoculum, the fungus was cultivated on moisture restricting culture medium as described by Machado et al.(2001), by spreading $2 \mathrm{ml}$ of the conidial suspension over the medium surface in culture plates of $20 \mathrm{~cm}$ diameter. After the fungus had uniformly grown over the entire surface of the medium, surface disinfested seeds were spread, in a single layer, over the colony and exposed to the fungal colonization for 24 or $48 \mathrm{~h}$ at $25^{\circ} \mathrm{C}$. The control seeds were placed on the medium without the fungus. After the each exposure period the seeds were removed from the culture and allowed to dry over a laboratory bench for $24 \mathrm{~h}$. To determine if the fungus had penetrated the seed coat, 25 seeds from each exposure period were surface disinfested by soaking for 1 minute in $2 \%$ sodium hypochlorite followed by rinsing with sterile tap water, and with the use of forceps the seed coat was separated from the embryo. The separated seed coats and the embryos were placed on moist blotter paper in culture plates and incubated for five days at $25^{\circ} \mathrm{C}$. All the seed coats from the both the exposure periods, but none of the corresponding embryos, yielded F. semitectum, which confirmed that only seed coat had been colonized and the fungus had not reached the embryo. Although all the seed coats yielded the fungus, the growth intensity was visually greater on seed coats from seeds exposed for $48 \mathrm{~h}$. The intensity of the fungal growth indicates higher inoculum in the seed coat, which however could not be quantified.

The surface disinfested inoculated and control seeds were planted in autoclaved sand in perforated plastic trays $(50 \mathrm{~cm} \mathrm{~L} \times 25 \mathrm{~cm} \mathrm{~W} \times 25 \mathrm{~cm} \mathrm{D})$. Each tray receiving 50 seeds represented one of the four replication of a exposure period. The data as to seedling emergence, and symptom development on the emerged seedling was monitored until appearance of the first permanent leaves. Isolations were made from the some of the randomly picked non-emerged seeds, and also from the lesions appearing on any part of the emerged seedlings.

The emergence rate of seeds exposed to the fungal colonization for $24 \mathrm{~h}$ was similar to that of control, but $36 \%$ of the seedlings showed a small (1 to $2 \mathrm{~mm}$ ) reddish dark brown necrotic lesion on the collar regions, without apparent effect on the seedling growth. The lesion expansion was slow and did not girdle the collar. The isolation from these lesions always yielded $F$. semitectum. On the other hand, when the seeds were exposed to fungal colonization for $48 \mathrm{~h}$ the seedling emergence was reduced by $25 \%$ and all the emerged seedlings had some kind of lesion on the roots, collar or the primary leaves and the isolation from all such lesions yielded $F$. semitectum (Figure 1). Negative geotropism occurred on 15\% of the seedlings. This symptom was characterized by the upward extension of the radical with the narcotized root tip, and the necrosis expanded to the entire radical, while the hypocotyl continued upward growth with the primary leaves buried in the sand. The necrosis on the radical continued to extend towards the hypocotyl inciting a dry rot (Figure 1A).

On all the remaining normal emerged seedlings, dark reddish-brown expanding lesions developed in the collar region, which with time girdled the hypocotyl. The lesions extended downwards to the roots resulting in the dry rot of the tap and lateral roots, leading to seedling mortality. Seedling damping-off without prior wilting or mortality was seen only occasionally. These lesions could be confused with those of Rhizoctonia solani, but differed in the sense that $R$. solani lesions are mostly soft rot-type and expand more rapidly upwards to hypocotyl resulting in damping-off, while $F$. semitectum lesions were dry rot-type, with more rapid expansion towards roots and the damping-off resulted from necrotic girdling of collar and the upper tap and lateral roots. 


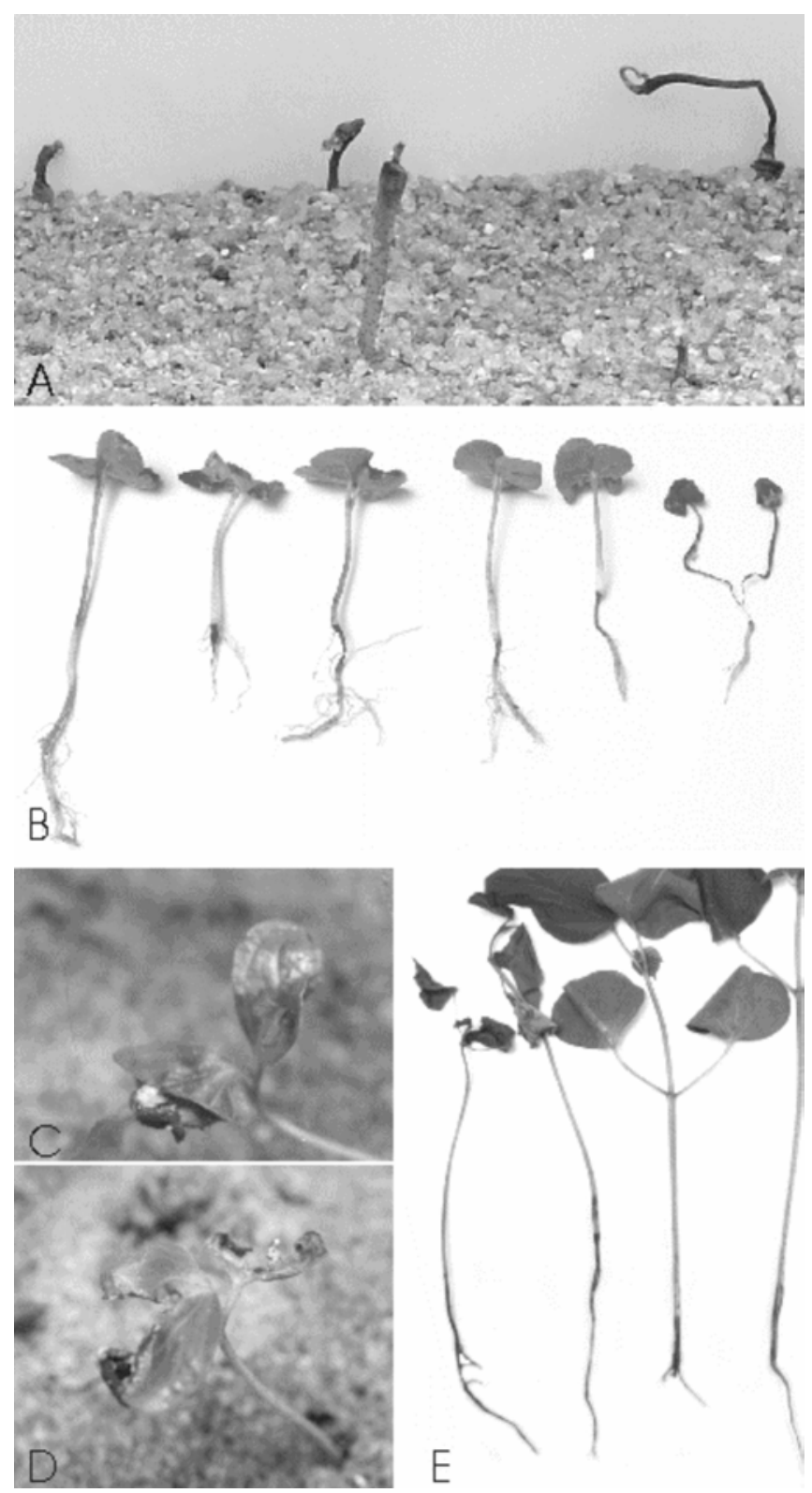

FIG. 1 - The range of symptoms incited by internally seed coat borne Fusarium semitectum on cotton (Gossypium hirsutum) seedlings emerging from infected seeds. A. Various stages of negative geotropism; B. Dry root rot of seedling collar and roots; C and D. Adherence of seed coat to the expanding primary leaf leading to leaf tearing; E. Root rot of post-seedling growing plants.

Extensive hypocotyl colonization by $F$. semitectum usually occurred after seedling mortality (Figure 1B). In many cases the shedding of seed coat was delayed, which remained attached to the primary leaves resulting in a extensive reddish brown lesion on the leaf leading to localized dry rot. The disease portion then fell out giving the leaf a shredded appearance (Figure 1C, D).

The surviving seedlings continued to grow, but most of them succumbed to extensive dry root rot (Figure 1E), which indicates that such plants may break or lodge under strong winds or heavy capsule load thus affecting total yield.

The results and observations from this study show for the first time that seedborne inoculum of $F$. semitectum in cotton can cause seed and root rot of seedlings and growing plants, only if the pathogen is internally seedborne, since no effect was observed when the seeds were surface inoculated. Even when internally seedborne, the degree of damage appears to be related to the quantity of inoculum present in the seed coat, since neither emergence rate nor appreciable seedling damage occurred if the seeds were exposed to the fungal colonization for only $24 \mathrm{~h}$. On the other hand, the exposure for $48 \mathrm{~h}$ resulted in appreciable seedling emergence loss and seedling damage, even though the fungus had not reached the embryonic tissues. The symptoms caused by the seedborne inoculum of $F$. semitectum may not be specific and can be confused with those caused by $R$. solani and the root rot symptoms of Fusarium solani. But none of these pathogens when seedborne, is known to cause negative geotropism in cotton. The continued root rot of post-seedling plants also suggests that the damage may not be limited only to the reduced stand due to poor emergence and seedling blight, but the seedborne inoculum can damage the growing plants, although the type of damage could not be ascertained at this stage.

The lack of correlation between the proportion of $F$. semitectum infected seeds in cottonseed lots and appearance of symptom in seedling test as seen in seed pathology tests, can be explained on the basis of inoculum potential in the seed coat, which on the other hand is reported to be related to the climatic conditions during the reproductive phase (Klich, 1986; Davis, 1977). Fusarium semitectum is known to cause considerable damage by inciting cotton boll rot in India and Columbia under hot and humid conditions (Krishnamurthy \& Verma, 1974; Restrepo et al., 1978), which indicates that seed colonization and thus seed inoculum potential may be related to the boll rot severity.

Although the occurrence of $F$. semitectum in cotton seeds and its pathogenicity on cotton seedling roots through artificial root inoculations has been reported earlier (Ray \& Mclaughlin, 1942), this is the first report to elucidate role of seedborne inoculum in causing an array of diseases on cotton that involves, reduced seedling emergence, negative geotropism, leaf tearing, and collar rot leading to root rot. The appearance and the severity of symptoms, however depends upon the inoculum potential in the seed coat.

\section{LITERATURE CITED}

DAVIS, R.G. Fuasrium species in the internal microflora of Mississippi cottonseed. Seed Science and Technology 5:587-591. 1977.

DHINGRA, O.D. \& ACUÑA, R.S. Patologia de semente de soja. Editora UFV, Viçosa, Brazil, 1997.

DHINGRA, O.D. \& MUCHOVEJ, J.J. Pod rot, seed rot and root rot of snap and dry bean caused by Fusarium semitectum. Plant Disease 
M.L.N. Costa et al.

Reporter 63:84-87. 1979.

DHINGRA, O.D. Internally seedborne Fusarium semitectum and Phomopsis sp. affecting dry and snap bean seed quality. Plant Disease Reporter 62:509-512. 1978.

JULIATII, F. \& RUANO, O. Algodão (Gossypium hirsutum L.): controle de doenças. In: Vale, F.X.R. \& Zambolim, L. (Eds.) Controle de Doenças das Plantas, Viçosa. DFP, UFV. 1997. pp.555-609

KLICH, M.A. Mycoflora of cotton seed from the Southern United States:A three year study of distribution and frequency. Mycologia 78:706-712. 1986.

KRISHNAMURTHY, V. \& VERMA, J.P. Preliminary studies on boll rot of cotton in India. Cotton Growing Review 51:226-229. 1974.

MACHADO, J.C., OLIVEIRA, J.A., VIEIRA, M.G.G.C. \& ALVES, M.C. Inoculação artificial de sementes de soja por fungos, utilizando solução de manitol. Revista Brasileira de Sementes 23:95-101. 2001.

PIZZINATTO, M.A., SOAVE, J. \& CIA, A. Levantamento de patógenos em sementes de seis cultivares de algodoeiro. Fitopatologia Brasileira 19:101-108. 1994.

RAY, W.W. \& McLAUGHLIN, J.H. Isolation and infection testes with seed- and soil -borne cotton pathogens. Phytopathology 32:231238. 1942.

RESTREPO, J.M., BARROS, A. \& VICTORIA, J.I. Pérdidas producidas por pudriciones de cásulas del algodonero (Gossypium hirsutum L.) en el Valle del Cauca durante el primer semestre de 1973. Fitopatologia Colombiana 7:32-45. 1978.

RONCADORI, R.W., MCCARTER, S.M. \& CRAWFORD J.L. Influence of fungi on cotton seed deterioration prior to harvest. Phytopathology 61:1326-1328.1971.

SOAVE, J. PIZZINATTO, M.A., RAZERA, L.F., CIA, E. \& AMBROSANO, G.M.B. Qualidade de sementes de algodão (Gossypium hirsutum L.) do ensaio regional de variadades paulistas. Summa Phytopatholologica 25:139-144. 1999. 